\title{
Analiza wpływu wytrzymałości betonów składowych jako czynnika kształtującego nośność niezbrojonego styku zespolonych elementów betonowych
}

\author{
Dominika Franczak-Balmas \\ Katedra Konstrukcji Budowlanych, Wydział Budownictwa i Architektury, \\ Politechnika Lubelska, e-mail:d.franczak@pollub.pl
}

Streszczenie: W artykule przedstawiono wyniki oraz analizę badań nośności styku próbek złożonych z dwóch betonów, badanych na rozciąganie przez rozłupywanie. Analizie poddano wpływ wytrzymałości składowych betonów zarówno „starego” jak i „nowego” na przyczepność w niezbrojonym styku betonowych elementów zespolonych.

Słowa kluczowe: betonowe konstrukcje zespolone, przyczepność, styk, nośność styku.

\section{Wprowadzenie}

Nośność styku oraz parametry go kształtujące mają istotne znaczenie szczególnie w analizach betonowych konstrukcji i elementów zespolonych. Przyczepność decyduje również o skuteczności napraw i wzmocnień elementów betonowych. W przypadku betonu wypełniającego złącza w konstrukcjach prefabrykowanych umożliwia połączenie prefabrykatów w tarcze. Konstrukcje betonowane z przerwami technologicznymi również stanowią swojego rodzaju konstrukcje zespolone [1, 2], a w ich analizach istotną kwestią jest rysoodporność, która zapewniona jest dzięki przyczepności.

Przyczepność jest też istotna w elementach ze stykami zbrojonymi - zerwanie przyczepności w styku poprzez przekroczenie naprężeń przyczepności oraz przemieszczenie lub rozwarstwienie wzajemne elementów zespolonych jest warunkiem decydującym o pracy zbrojenia zszywającego i powstania w nim naprężeń [3]. Naprężenia przyczepności wpływają więc na pracę statyczną elementów zespolonych ze stykami zbrojonymi.

Podstawowym problemem w analizach pracy statycznej i projektowaniu elementów zespolonych jest uwzględnienie w obliczeniach konkretnych wartości naprężeń przyczepności w stykach oraz nieciągłościach betonowania. Pomimo wielu prób nie udało się dotychczas stworzyć uniwersalnego algorytmu obliczeń nośności styku, czy to algebraicznego czy modelu MES, ponieważ w analizach na wynik rozwiązania zagadnienia istotny wpływ ma dobór parametrów styku, w tym również uwzględnienie efektu skali [4].

$\mathrm{Z}$ uwagi na fakt, iż określenie parametrów styku jest niezbędne do opracowania modelu obliczeniowego pracy styku dwóch betonów, niezbędne wydaje się kontynuowanie badań laboratoryjnych określających czynniki kształtujące przyczepność, wraz z jednoczesną ich weryfikacją na podstawie modelu MES, opierającego się na doborze parametrów styku i parametrów materiałowych. Niniejsza praca jest jednym z elementów realizacji pierwszego z ogniw takiego podejścia. 


\section{Czynniki kształtujące nośność styku i wpływ stanu naprężeń na tę nośność}

Rozwiązanie zagadnienia, jakim jest określenie konkretnych wartości naprężeń przyczepności jest procesem złożonym, ponieważ na nośność styku wpływ ma wiele czynników. Czynnikami kształtującymi nośności styku są: szorstkość powierzchni, wytrzymałość łączonych betonów, rodzaj cementu [5], kruszywa, dodatki mineralne np. w postaci popiołów lotnych [6], stosunek w/c [6], wiek betonu pierwotnego oraz stopień dojrzałości betonu „nowego" $[5,7]$, stosowanie warstw sczepnych, warunki pielęgnacji w tym temperatura, stopień wilgotności podłoża a także efekt skali [4].

\subsection{Wytrzymałość betonu}

Wpływ wytrzymałości łączonych betonów na nośność styku nie jest jednoznacznie opisany w literaturze. Tradycyjnie za miarodajną uznawano wytrzymałość słabszego z betonów i zazwyczaj analizy nośności styku przeprowadzane są w odniesieniu właśnie do tej wytrzymałości.

W pracy [8] autorzy zaobserwowali, że im wyższa jest wytrzymałości nadbetonu tym większa jest nośność styku, ale przy niższych klasach betonu „nowego” stosunek nośności styku do jego wytrzymałości na ściskanie jest wyższy. Stosunek ten może być odniesiony do współczynnika efektywności zespolenia [3], bądź skorygowanej wartości współczynnika efektywności zespolenia [5] wyrażającego stosunek nośności styku próbki zespolonej utożsamianej z jej zarysowaniem do wytrzymałości próbki jednolitej słabszego z betonów badanych w tym samym schemacie.

W literaturze nie odnaleziono jednak jednoznacznych informacji o wpływie wytrzymałości betonu „starego" i betonu „nowego”, dlatego też podjęto badania próbek zespolonych, w których łączono betony charakteryzujące się różnymi wytrzymałościami.

\subsection{Stan naprężeń w styku}

Wyniki badań przyczepności ściśle zależą od rodzaju próbki, a w szczególności od stanu naprężeń w styku. Zagadnienie to, wraz z zestawieniem typów próbek stosowanych w badaniach przyczepności betonu analizowano szczegółowo m.in. w monografii [3].

W niniejszej pracy zrelacjonowane są badania próbek zespolonych ze stykiem rozciąganym. Badania wykonano $\mathrm{w}$ schemacie rozciągania przez rozłupywanie $\mathrm{z}$ uwagi na mniejszy rozrzut wyników badań i łatwiejszą realizację niż w badaniach na osiowe rozciąganie.

\section{Program i przebieg badań}

Celem badań było rozpoznanie, jaki wpływ na przyczepność w elementach zespolonych typu „beton-beton” mają wytrzymałości łączonych betonów, zarówno „nowego” jak i „starego". Badania główne wykonano na zespolonych próbkach sześciennych o wymiarach 150x150x150 mm poddanych rozciąganiu przez rozłupywanie. Styk między betonami usytuowany był pionowo, w osi przykładanych sił. Schemat badań przedstawiono na Rys. 1. 


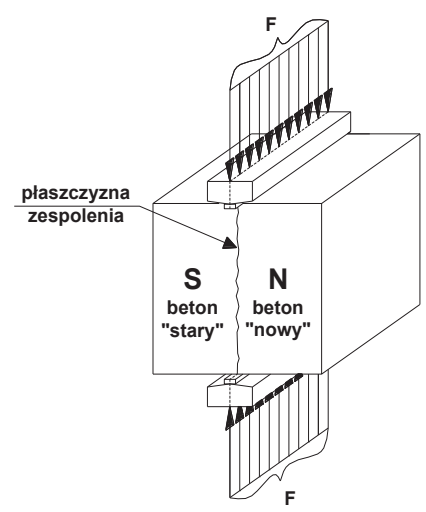

Rys. 1. Schemat badań próbek zespolonych

Próbki zostały wykonane dwuetapowo. W pierwszym etapie w formach układano beton „stary” (Rys. 2), pozostałą przestrzeń wypełniając styropianem. Po okresie 14 dni dojrzewania betonu „starego” dobetonowywano „nowy” beton. Nie czekano na osiągnięcie wieku 28 dni, ponieważ przy odpowiednich warunkach pielęgnacji betonu naprężenia przyczepności już w pierwszych kilkunastu dniach dojrzewania osiągają ok. 80-90 procent wartości 28-dniowej [7].

Powierzchnię styku przygotowywano poprzez oczyszczenie z mleczka cementowego stalowymi szczotkami oraz nawilżenie wodą.

Składy mieszanek betonowych wykonanych z CEM I 32,5 R przedstawiono w Tab. 1. Podczas dojrzewania próbki poddawane były pielęgnacji poprzez nawilżanie wodą. Badania realizowano po 14 dniach dojrzewania betonu „nowego”.

Tabela 1. Składy mieszanek betonowych

\begin{tabular}{cccccc}
\hline beton & cement & woda & piasek & żwir & w/c \\
\hline & {$\left[\mathrm{kg} / \mathrm{m}^{3}\right]$} & {$\left[1 / \mathrm{m}^{3}\right]$} & {$\left[\mathrm{kg} / \mathrm{m}^{3}\right]$} & {$\left[\mathrm{kg} / \mathrm{m}^{3}\right]$} & \\
\hline $\mathrm{C} 16 / 20$ & 330 & 205 & 700 & 1114 & 0,62 \\
\hline $\mathrm{C} 30 / 37$ & 420 & 200 & 500 & 1300 & 0,48 \\
\hline $\mathrm{C} 35 / 45$ & 450 & 177 & 461 & 1312 & 0,39 \\
\hline
\end{tabular}

Badania podzielono na pięć serii próbek. Każdą serię próbek oznaczono literą R, symbolizującą badanie nośności na rozciąganie przez rozłupywanie oraz liczbami określającymi klasy betonów składowych, dla których spełnione były kryteria zgodności wytrzymałości na ściskanie - pierwsza liczba odnosi się do klasy betonu „starego” natomiast druga - betonu ,nowego”.

Sposób oznaczenia poszczególnych serii próbek przedstawia Tab. 2.

Tabela 2. Sposób oznaczenia serii próbek

\begin{tabular}{ccc}
\hline seria & klasa wytrzymałości betonu ,starego” & klasa wytrzymałości betonu ,nowego” \\
\hline R20/37 & $\mathrm{C} 16 / 20$ & $\mathrm{C} 30 / 37$ \\
\hline $\mathrm{R} 37 / 37$ & $\mathrm{C} 30 / 37$ & $\mathrm{C} 30 / 37$ \\
\hline $\mathrm{R} 45 / 15$ & $\mathrm{C} 35 / 45$ & $\mathrm{C} 12 / 15$ \\
\hline $\mathrm{R} 45 / 30$ & $\mathrm{C} 35 / 45$ & $\mathrm{C} 25 / 30$ \\
\hline $\mathrm{R} 45 / 37$ & $\mathrm{C} 35 / 45$ & $\mathrm{C} 30 / 37$ \\
\hline
\end{tabular}


a)

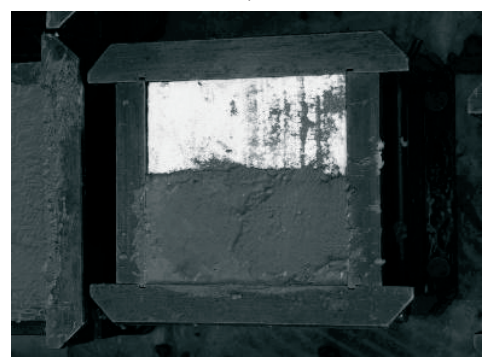

b)

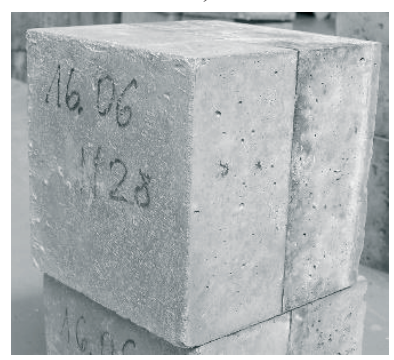

Rys. 2. Próbki zespolone poddane badaniom: a) forma z ułożonym betonem „starym”, b) próbka zespolona

\section{Wyniki badań}

Szczegółowe wyniki badań próbek zestawiono w Tab. 3. Podano tu parametry wytrzymałościowe użytych materiałów - średnie wytrzymałości na ściskanie i rozciąganie oraz średnie nośności styku próbek zespolonych na rozciąganie $\left(\sigma_{c r m, z}\right)$, utożsamianą z rysoodpornością styku [5] (Rys. 3). Średnie wytrzymałości próbek monolitycznych wyznaczono z wyników badań trzech próbek natomiast nośność styku na rozciąganie pięciu próbek.

Wytrzymałości na rozciąganie osiowe próbek monolitycznych jak i nośność styku próbek zespolonych ustalono na podstawie badań próbek rozłupywanych korzystając ze wzoru normowego [9]:

$$
f_{c t m}=0,9 \cdot f_{c t m, s p}
$$

Tabela 3. Wyniki badań próbek

\begin{tabular}{ccccccccc}
\hline \multirow{2}{*}{ seria } & \multicolumn{3}{c}{ wytrzymałość betonów składowych } & & \multicolumn{2}{c}{ nośność styku na rozciąganie } \\
\cline { 2 - 5 } & \multicolumn{2}{c}{ beton stary } & \multicolumn{2}{c}{ beton nowy } & & & \\
\cline { 2 - 6 } & $f_{c m}$ & $f_{c t m}$ & $f_{c m}$ & $f_{c t m}$ & $\sigma_{c r m, z}$ & Sfcrm,z & $v_{f c r m, z}$ \\
\hline & {$[\mathrm{MPa}]$} & {$[\mathrm{MPa}]$} & {$[\mathrm{MPa}]$} & {$[\mathrm{MPa}]$} & {$[\mathrm{MPa}]$} & {$[\mathrm{MPa}]$} & {$[\%]$} \\
\hline $\mathrm{R} 20 / 37$ & 25,78 & 2,14 & 45,70 & 2,92 & 0,74 & 0,02 & $2,44 \%$ \\
\hline $\mathrm{R} 37 / 37$ & 45,26 & 2,74 & 45,50 & 2,75 & 0,88 & 0,08 & $9,21 \%$ \\
\hline $\mathrm{R} 45 / 15$ & 50,23 & 3,03 & 21,56 & 1,86 & 0,71 & 0,06 & $8,86 \%$ \\
\hline $\mathrm{R} 45 / 30$ & 50,58 & 2,79 & 35,90 & 2,81 & 0,82 & 0,06 & $7,49 \%$ \\
\hline $\mathrm{R} 45 / 37$ & 49,70 & 2,81 & 46,68 & 2,90 & 0,99 & 0,15 & $14,64 \%$ \\
\hline
\end{tabular}

W badaniach wykorzystano system optyczny Aramis, umożliwiający m.in. obserwację obrazu propagacji rys. Obrazy powierzchni próbki wraz z zaobserwowanym zarysowaniem w wybranych kolejnych etapach obciążenia pokazano na Rys. 3, analiza wyników badań uzyskanych dzięki systemowi Aramis będzie przedmiotem kolejnej publikacji.

Na Rys. 4 i 5 przedstawiono wyniki badania wytrzymałości na ściskanie i rozciąganie betonów składowych, natomiast na Rys. 6 wyniki badań nośności styku. Rozrzuty wyników nośności styku na rozciąganie osiągały wartości od $2,4 \%$ do około $9 \%$, a w przypadku jednej serii - do 15\%. Zniszczenie wszystkich próbek zespolonych nastąpiło poprzez rozwarstwienie w płaszczyźnie (zniszczenie adhezyjne) styku. 
a)

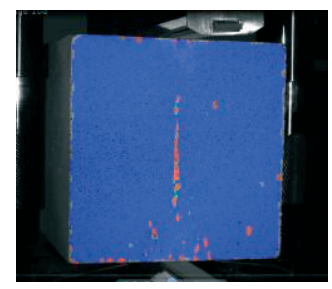

b)

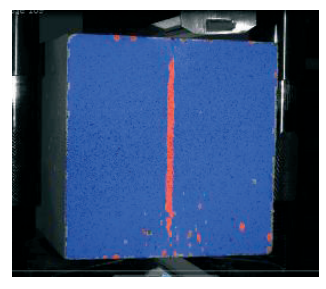

c)

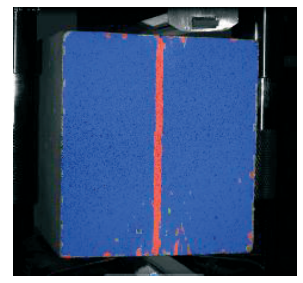

d)

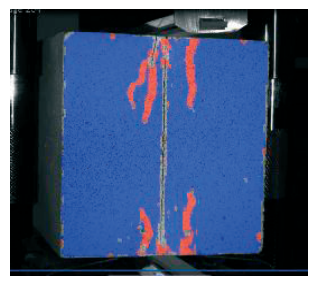

Rys. 3. Wybrane obraz propagacji rys na powierzchni próbki zaobserwowane w programie Aramis: a),b) kolejne etapy zarysowania styku próbki, c) rozwarstwienie w płaszczyźnie styku w momencie utraty nośności styku, d) końcowy etap badania po rozwarstwieniu styku tuż przed osiągnięciem nośności próbki zespolonej

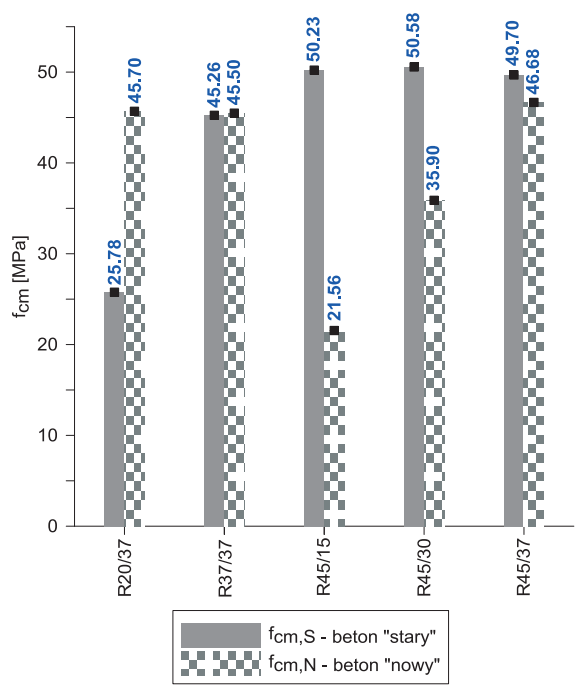

Rys. 4. Wytrzymałość na ściskanie betonów składowych

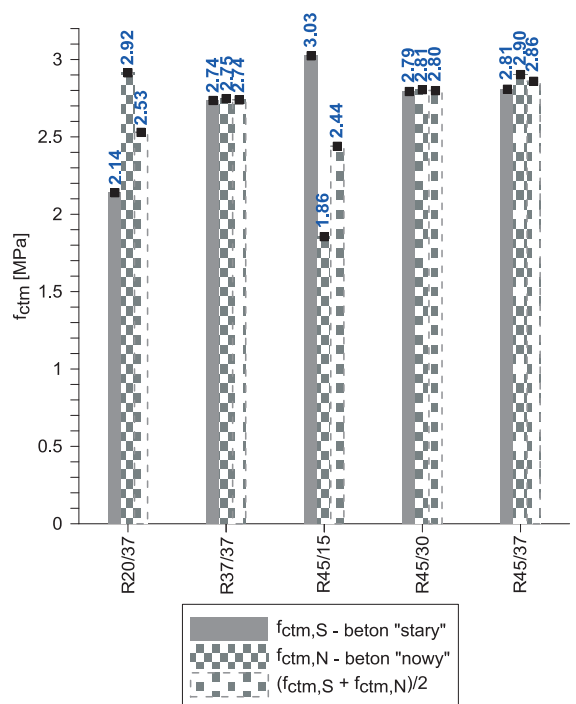

Rys. 5. Wytrzymałość na rozciąganie betonów składowych

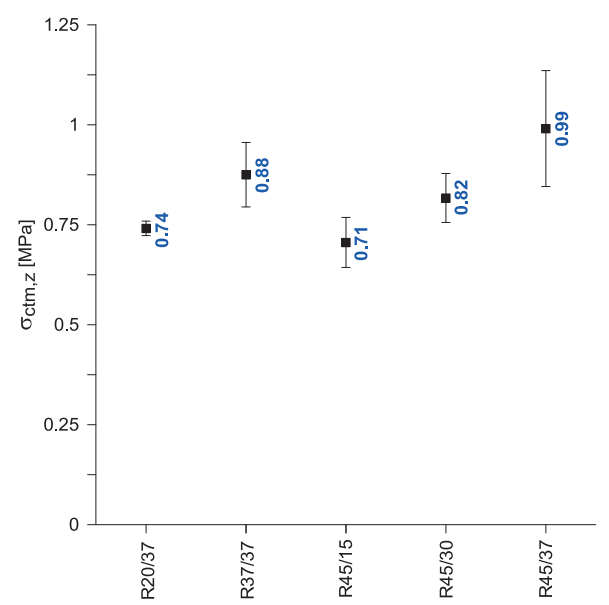

Rys. 6. Nośność styku na rozciąganie próbek zespolonych 


\section{Analiza wyników}

Do analizy wyników badań zastosowano współczynnik efektywności zespolenia $\alpha_{c r}$ (Rys. 7) zdefiniowany jako:

$$
\alpha_{c r}=\frac{\sigma_{c r m, z}}{f_{c t m}}
$$

gdzie: $\sigma_{c r m, z}$ - średnie naprężenia rysujące styk próbki zespolonej, $f_{c t m}$ - średnia wytrzymałość na rozciąganie jednego $\mathrm{z}$ betonów.

Najpierw obliczono współczynnik efektywności zespolenia tradycyjnie, a więc w stosunku do wytrzymałości słabszego z betonów. Wartości tego współczynnika zobrazowano na Rys. 7. Nie zaobserwowano tu wyraźnej prawidłowości.

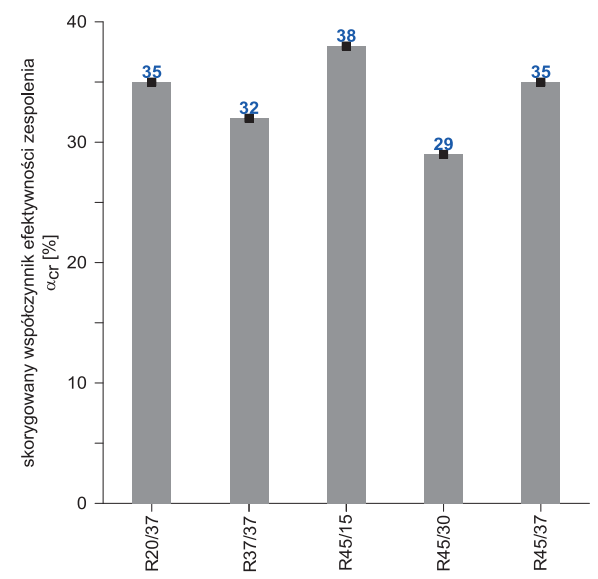

Rys. 7. Współczynnik efektywności zespolenia styku próbek obliczony z uwzględnieniem wytrzymałości słabszego z łączonych betonów

Zdecydowano zatem o obliczeniu dwóch kolejnych współczynników efektywności. Dla serii o jednakowej wytrzymałości betonu „starego” obliczono współczynnik efektywności względem wytrzymałości betonu „nowego” (Rys. 8), a dla serii o jednakowej wytrzymałości betonu „nowego” obliczono współczynnik efektywności względem wytrzymałości betonu „starego” (Rys. 9).

Analizując Rys. 8 można stwierdzić, że w przypadku jednakowej wytrzymałości na rozciąganie betonu „starego” efektywność zespolenia rośnie. Z kolei na podstawie Rys. 9 można stwierdzić, że wytrzymałość betonu „starego" decyduje o nośności styku w próbkach, w których jednakową klasę wytrzymałości miał beton „nowy” a różnicowano wytrzymałość betonu ,starego".

Porównując wyniki badań w dwóch grupach próbek pokazanych na Rys. 8 (R45/15, R45/30 i R45/37) i na Rys. 9 ( R20/37 R37/37, i R45/37) można stwierdzić także, że niższą nośność styku zaobserwowano w przypadku łączenia dwóch betonów o większej różnicy wytrzymałości na rozciąganie i ściskanie. Najniższą nośność styku osiągały próbki R20/37 oraz R45/15 o najmniejszych wytrzymałościach jednego z betonów składowych, ale także największej różnicy wytrzymałości, wyniosła ona odpowiednio 0,74 MPa i 0,71 MPa. Próbki zespolone w których różnica klas wytrzymałości łączonych betonów była mniejsza osiągały nośności styku $\left(\sigma_{c r m, z}\right)$ wyższe od nośności styku próbek R20/37 i R45/15 od 11\% do 38\%. 


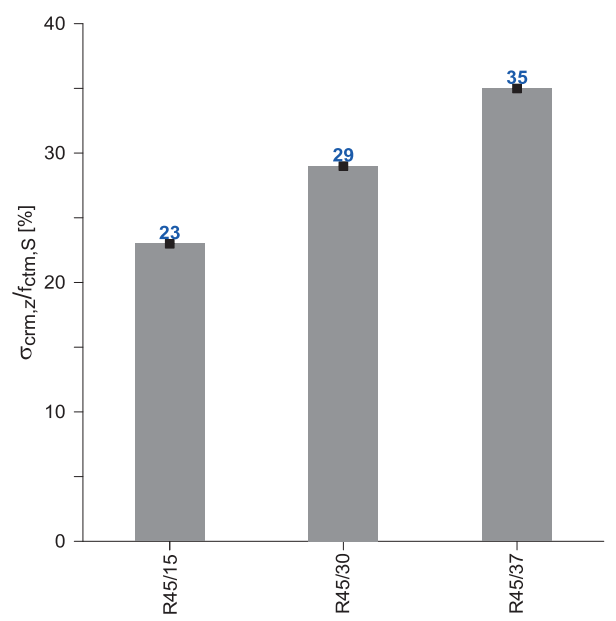

Rys. 8. Stosunek nośności próbki zespolonej do wytrzymałości na rozciąganie betonu "starego" próbek serii z różnicowaną klasą nadbetonu

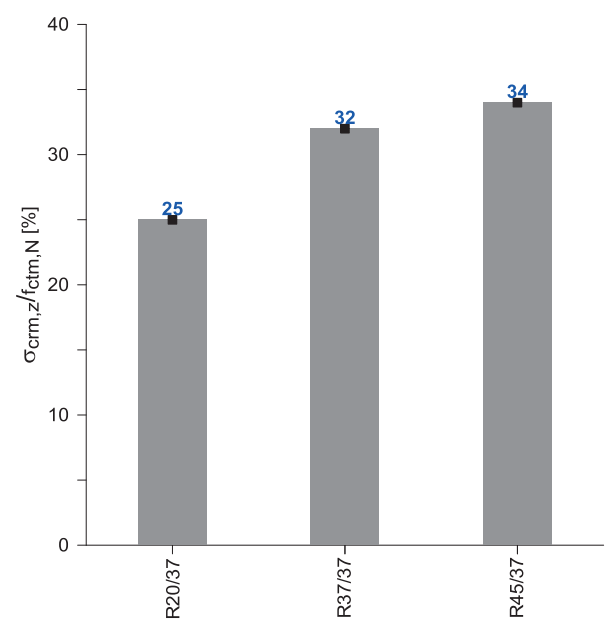

Rys. 9. Stosunek nośności próbki zespolonej do wytrzymałości na rozciąganie betonu "nowego" próbek serii z różnicowaną klasą betonu pierwotnego

Stwierdzenie, że efektywność zespolenia zależy od obydwu betonów skłoniło do poszukiwania tego wpływu. Jako pierwsze przybliżenie wyznaczono średni współczynnik efektywności zespolenia $\beta_{\text {cr }}$ (Rys. 10) zdefiniowany jako:

$$
\beta_{c r}=\frac{\sigma_{c r m, z}}{\frac{f_{c t m, S}+f_{c t m, N}}{2}}
$$

gdzie: $\sigma_{c r m, z}-$ średnie naprężenia rysujące styk próbki zespolonej, $f_{c t m, S}$ - średnia wytrzymałość na rozciąganie betonu „starego”, $f_{c t m, N}$-średnia wytrzymałość na rozciąganie betonu „nowego".

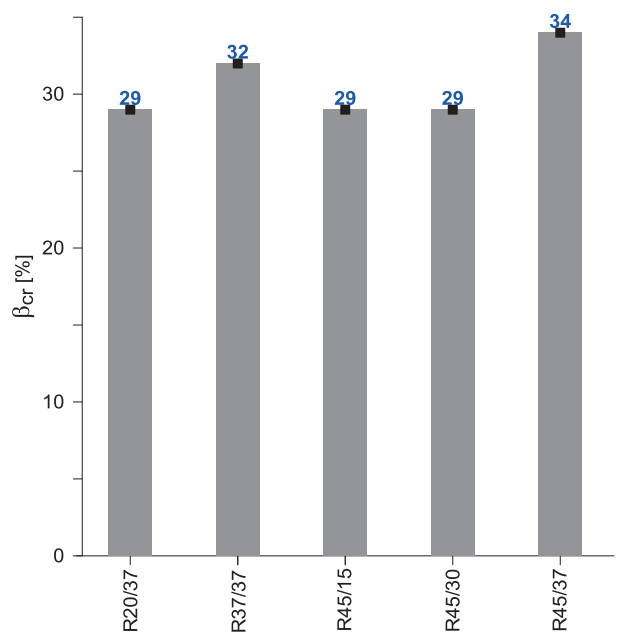

Rys. 10. Średni współczynnik efektywności zespolenia 
Analizując Rys. 10 można stwierdzić, iż średni współczynnik efektywności zespolenia-wynosił około $30 \%$ i osiągał wartości od $29 \%$ do $34 \%$, przy czym nieco wyższe wartości na poziomie 32\%-34\% uzyskano w przypadku łączenia betonów charakteryzujących się małą różnicą w wytrzymałościach na rozciąganie oraz ściskanie natomiast w pozostałych seriach próbek zespolonych współczynnik ten wyniósł 29\%.

\section{Wnioski}

Na podstawie przeprowadzonych badań, w odniesieniu do nośności styku dwóch betonów można stwierdzić, co następuje:

- Przy jednakowym sposobie przygotowania powierzchni styku, nośność próbek zespolonych z stykiem rozciąganym, będąca miarą przyczepności panującej w styku, zależy od wytrzymałości obydwu łączonych betonów, „nowego” i „starego”.

- Dobrym miernikiem przyczepności jest średni współczynnik efektywności zespolenia opisany wzorem (3).

- Niższą nośność styku uzyskano w przypadku łączenia dwóch betonów o większej różnicy wytrzymałości na rozciąganie i ściskanie.

\section{Literatura}

1. Halicka A., Franczak D., Fronczyk J. Analiza przyczyn zarysowań cylindrycznego zbiornika żelbetowego ujawnionych podczas próby szczelności. Przegląd Budowlany 4 (2012) 35-41.

2. Kamiński M., Maj M., Kmiecik P. Wpływ technologii ksztaltowania przerw roboczych w aspekcie zachowania właściwej nośności ścian zbiorników i kominów żelbetowych. Przegląd Budowlany 4 (2012) 125-129.

3. Halicka A. Studium naprężeń i odkształceń w płaszczyźnie styku i strefie przypodporowej elementów zespolonych z udziatem betonów skurczowych i ekspansywnych. Wydawnictwa Uczelniane, Lublin 2007.

4. Halicka A., Franczak-Balmas D. The size effect in monolithic and composite concrete members. Part 2, Cement Lime Concrete 1 (2014) 262-266.

5. Franczak D., Halicka A. Wplyw wieku betonu na nośność styku w elementach zespolonych typu „, beton-beton”. Przegląd Budowlany 1 (2012) 46-51.

6. Hak-Chul S., Zhifu W. Interfacial properties between New and Old Concretes. $2^{\text {nd }}$ International Conference on Sustainable Construction Materials and Technologies, Ancona, Italy 2010.

7. Halicka A., Franczak D. Rozwój przyczepności między dwoma betonami w czasie twardnienia betonu. Wydawnictwa Uczelniane, Lublin 2009.

8. Beushausen H., Alexander M.G. Bond strength development between concretes of different ages. Magazine of Concrete Research 60(1) (2008) 65-74.

9. PN-EN 1992-1-1: wrzesień 2008 Eurocod 2 Projektowanie konstrukcji z betonu Część 1-1: Reguty ogólne i reguty dla budynków. 


\title{
An analysis of the impact strength of concrete components as a factor influencing the bond strength in unreinforced composite concrete elements
}

\author{
Dominika Franczak-Balmas \\ Lublin University of Technology, Faculty of Civil Engineering and Architecture, \\ e-mail:d.franczak@pollub.pl
}

\begin{abstract}
The article presents the results and analysis of the research of the bond strength between two concrete parts in composite member investigated by tensile splitting test. The study was conducted on five groups of specimens differing in terms of classes of connected concrete. The impact of strength of the concrete components of both "old" and "new" on bond strength in the unreinforced concrete composite elements is discussed.
\end{abstract}

Keywords: composite members, bond, bond strength, adhesion. 
